\title{
PENGARUH TINGKAT BAGI HASIL DAN BI RATE TERHADAP BESARNYA TABUNGAN MUDHARABAH PADA BANK SYARIAH PERIODE 2013-2018
}

\author{
Falahuddin $^{1}$, Muchsal Mina ${ }^{2}$ \\ ${ }^{1,2}$ Prodi Akuntansi Fakultas Ekonomi dan Bisnis Universitas Malikussaleh Lhokseumawe \\ Falahuddin.hasb@gmail.com¹,Muchsalmina29@gmail.com ${ }^{2}$
}

\begin{abstract}
This study aims to analyze the Effect of Profit-Sharing Rate and BI Rate on the amount of Mudharabah Savings in Islamic Banks from 2013 to 2018. This study uses secondary data in the form of Islamic Bank financial statements accessed on www.idx.com. The data analysis method used is multiple linear regression analysis. The sample used in this study is 12 banks. The results show that the profit-sharing rate partially has a positive and significant effect on Mudharabah savings in Islamic banks in Indonesia, the BI rate has no effect on Mudharabah savings in Islamic banks in Indonesia. Simultaneously, the profit-sharing rate and BI rate have a positive and significant effect on Mudharabah savings in Islamic banks in Indonesia.
\end{abstract}

Keywords: Profit Sharing Rate, BI Rate, Mudharabah Savings

\section{PENDAHULUAN}

Simpanan mudharabah (tabungan) merupakan salah satu produk simpanan yang diminati masyarakat, seperti halnya deposito dan giro. Jenis simpanan mudharabah yaitu simpanan bank syariah yang penarikannya hanya dapat dilakukan menurut syarat-syarat tertentu. Faktor yang berperan penting dalam perkembangan bank syariah adalah pola ketertarikan masyarakat terhadap budaya menyimpan uangnya sebagai bentuk investasi. Ketertarikan masyarakat untuk menginvestasikan dananya tersebut dengan harapan memperoleh keuntungan yang lebih besar (Ilmiah, 2013).

Dalam prinsip mudharabah, penyimpan atau deposan bertindak sebagai pemilik modal (shahibulmaal) sedangkan bank bertindak sebagai pengelola (mudharib). Dalam kapasitasnya sebagai mudharib, bank dapat melakukan berbagai macam usaha yang tidak bertentangan dengan prinsip syariah yaitu mudharabah dengan pihak lain. Semua modal harus dinyatakan dengan jumlah dalam bentuk tunai dan bukan piutang.Pembagian keuntungan harus dinyatakan dalam bentuk nisbah dan dituangkan dalam akad pembukaan rekening.Bank sebagai mudharib menutup biaya operasional tabungan dengan menggunakan nisbah keuntungan yang menjadi haknya dan tidak diperkenankan mengurangi nisbah keuntungan nasabah tanpa persetujuan yang bersangkutan (Wulansari, 2012).

Reswari (2010), menyatakan bahwa salah satu faktor yang dapat digunakan untuk menilai tingkat keberhasilan bank syariah adalah dengan melihat besarnya Dana Pihak Ketiga (DPK). Bank mengharapkan DPK yang semakin meningkat, demi maksimalisasi pembiayaan, pihak manajemen berkepentingan dengan besarnya DPK dalam kaitannya dengan penilaian kinerja manajerial, sedangkan bank sebagai suatu perusahaan juga mengharapkan tingginya DPK dalam kaitannya dengan optimalisasi laba perusahaan. DPK yang masuk ke bank syariah dibedakan dalam tiga bentuk, yaitu dalam bentuk giro, tabungan, dan deposito. Jumlah dana pihak ketiga berasal dari dana yang disimpan nasabah kepada Bank Syariah berdasarkan akad yang tidak bertentangan dengan prinsip syariah dalam bentuk simpanan giro, simpanan tabungan, simpanan deposito, atau bentuk lainnya yang disamakan dengan itu. Dana-dana masyarakat yang disimpan dalam bank merupakan sumber dana terbesar yang paling diandalkan bank.

Jika dalam mekanisme ekonomi konvensional menggunakan bunga, maka dalam mekanisme ekonomi Islam menggunakan instrumen bagi hasil. Salah satu bentuk instrument kelembagaan yang menerapkan instrument bagi hasil adalah bisnis dalam lembaga keuangan syari'ah. Sistem bagi hasil dapat dijadikan dasar pertimbangan dalam menyusun kebijakan moneter, sebab perilaku bagi hasil akan mempengaruhi kondisi perekonomian suatu negara. Prinsip utama yang dianut oleh bankbank Islam adalah larangan riba (bunga) dalam berbagai bentuk transaksi, sebagai pengganti dari mekanisme bunga, sebagian ulama meyakini bahwa dalam pembiayaan proyek-proyek individual, instrumen yang paling baik adalah bagi hasil (profit sharing) (Fatmala 2015).

Bunga merupakan penambahan, perkembangan, peningkatan dan pembesaran yang diterima pemberi pinjaman dari peminjam dari jumlah pinjaman pokok sebagai imbalan karena menangguhkan atau berpisah dari sebagian modalnya selama periode waktu tertentu. Suku bunga adalah tingkat bunga yang dinyatakan dalam persen dan dalam waktu tertentu (per bulan atau per tahun).Tingkat bunga merupakan salah satu pertimbangan seseorang untuk menabung atau mendepositokan dananya pada bank.Konsep mengenai bunga adalah sangat berlawanan dengan konsep yang ada pada sistem perbankan syariah, perbankan syariah menekankan pada profit sharing. Pada bank syariah simpanan yang ditabung atau didepositokan akan digunakan sebagai pembiayaan 
ke sektor rill dan kemudian hasil atau keuntungan yang didapat akan disepakati menurut nisbah yang disepakatai bersama. Konsekuensi yang didapat pada sistem mudharabah adalah adanya untung rugi, jika keuntungan yang didapat besar maka dana bagi hasil yang didapat juga besar, tetapi jika rugi maka keduanya mengandung resiko atas usaha tersebut.

Penyimpanan dana merupakan salah satu fungsi dari bank, dan tak bisa dipungkiri bahwa tinggi rendahnya suku bunga merupakan faktor yang sangat menentukan pilihan para calon nasabah akan menabung di bank yang mana. Saat tingkat suku bunga lebih tinggi dari pada tingkat bagi hasil, maka nasabah memilih untuk menyimpan uangnya di bank konvensional dan sebaliknya jika tingkat bagi hasil lebih besar dari tingkat suku bunga, maka nasabah lebih memilih untuk menyimpan dananya di bank syariah (Nurjannah, 2017).

Penelitian sebelumnya mengenai pengaruh tingkat bagi hasil dan tingkat suku bunga terhadap besarnya tabungan mudharabah, dari penelitian terdahalu diantaranya adalah variabel tingkat bagi hasil.Penelitian yang dilakukan oleh Ghafur (2003), menyimpulkan tingkat bagi hasil tidak berpengaruh signifikan terhadap simpanan deposito mudharabah.Aniswah (2011), hasil penelitiannya menunjukkan bahwa variabel tingkat bagi hasil tidak berpengaruh signifikan terhadap simpanan deposito mudharabah. Penelitian yang dilakukan oleh Ana (2001), dalam penelitiannya menunjukkan bahwa tingkat bagi hasil berpengaruh positif terhadap simpanan deposito mudharabah. Rizqiana (2010), menyimpulkan bahwa tingkat bagi hasil berpengaruh signifikan positif terhadap simpanan deposito mudharabah.Reswari (2010), hasilnya adalah variabel jumlah bagi hasil berpengaruh positif terhadap simpanan mudharabah.Marifat (2016), hasil penelitiannya menunjukkan tingkat bagi hasil berpengaruh signifikan terhadap jumlah deposito mudharabah secara simultan. Hal ini dikarenakan apabila tingkat bagi hasil meningkat, akan semakin banyak para deposan yang menginvestasikan dananya di bank.

Variabel tingkat suku bunga, penelitian yang dilakukan oleh Haron (2005), hasil penelitiannya adalah suku bunga berpengaruh negatif terhadap dana yang dihimpun oleh bank Islam di Malaysia. Semakin besar tingkat bunga pada bank konvensional maka semakin kecil dana yang dihimpun oleh bank Islam. Sedangkan penelitian yang dilakukan oleh Ghafur (2003), mengungkapkan suku bunga tidak berpengaruh signifikan terhadap simpanan mudharabah di bank Muamalat Indonesia. Rusmawati (2016), hasil penelitiannya menunjukkan bahwa ringkat suku bunga deposito berjangka 3 bulan tidak berpengaruh terhadap besarnya simpanan mudharabah pada bank umum syariah di Indonesia. Reswari (2010), hasil penelitiannya berdasarkan uji parsial (uji t) menunjukkan bahwa, variabel tingkat suku bunga (Interest Rate) tidak berpengaruh terhadap simpanan mudharabah dan berdasarkan uji simultan (uji F) variabel tingkat suku bunga berpengaruh terhadap simpanan mudharabah.
Berdasarkan uraian di atas, maka peneliti tertarik untuk melakukan penelitian terkait simpanan mudharabah. Oleh karena itu peneliti melakukan penelitian dengan judul "Pengaruh Tingkat Bagi Hasil dan BI Rate Terhadap Besarnya Tabungan Mudharabah Pada Bank Syariah Periode 2013-2018".

\section{TINJAUAN PUSTAKA \\ Tabungan Mudharabah \\ Pengertian Tabungan}

Tabungan merupakan salah satu jenis dari produk simpanan. Bagi bank, simpanan adalah sumber dana utama yang sejatinya ditahan untuk kepentingan transaksi. Bank-bank memiliki produk giro, deposito berjangka, dan tabungan. Menurut Undang-Undang Perbankan Nomor 10 Tahun 1998, Tabungan adalah simpanan yang penarikannya hanya dapat dilakukan menurut syarat tertentu yang disepakati, tetapi tidak dapat ditarik dengan cek, bilyet giro, dan atau alat lainnya yang dipersamakan dengan itu (Purwaningsih, 2016).

\section{Pengertian Tabungan Mudharabah}

Tabungan mudharabah mempunyai sifat dana investasi, penarikan hanya dapat dilakukan pada periode/waktu tertentu, insentif berupa bagi hasil, dan pengembalian dana tidak dijamin dikembalikan semua.

Tabungan Mudharabah adalah tabungan yang dijalankan berdasarkan akad mudharabah. Mudharabah mempunyai dua bentuk, yakni mudharabah mutlaqah dan mudharabah muqayyadah, yang perbedaan utama di antara keduanya terletak pada ada atau tidaknya persyaratan yang diberikan pemilik dana kepada bank dalam mengelola hartanya. Dalam hal ini, bank syariah bertindak sebagai mudharib (pengelola dana), sedangkan nasabah bertindak sebagai shahibul mal (pemilik dana). Bank syariah dalam kapasitasnya sebagai mudharib, mempunyai kuasa untuk melakukan berbagai macam usaha yang tidak bertentangan dengan prinsip syariah serta mengembangkannya, termasuk melakukan akad mudharabah dengan pihak lain. Namun, di sisi lain, bank syariah juga memiliki sifat sebagai seorang wali amanah (trustee), yang berarti bank harus berhati-hati atau bijaksana serta beritikad baik dan bertanggung jawab atas segala sesuatu yang timbul akibat kesalahan atau kelalaiannya.

Dari hasil pengelolaan dana mudharabah, bank syariah akan membagihasilkan kepada pemilik dana sesuai dengan nisbah yang telah disepakati dan dituangkan dalam akad pembukaan rekening. Dalam mengelola dana tersebut, bank tidak bertanggung jawab terhadap kerugian yang bukan disebabkan oleh kelalaiannya. Namun, apabila yang terjadi adalah mismanagement (salah urus), bank bertanggung jawab penuh terhadap kerugian tersebut.

Dalam mengelola harta mudharabah, bank menutup biaya operasional tabungan dengan menggunakan nisbah keuntungan yang menjadi 
haknya. Di samping itu, bank tidak diperkenankan mengurangi nisbah keuntungan nasabah penabung tanpa persetujuan yang bersangkutan. Sesuai dengan ketentuan yang berlaku, PPH bagi hasil tabungan mudharabah dibebankan langsung ke rekening tabungan mudharabah pada saat perhitungan bagi hasil (Purwaningsih, 2016).

\section{Tujuan dan Manfaat Tabungan Mudharabah}

$$
\text { Menurut Latumaerissa dalam }
$$

(Purwaningsih 2016), Tujuan dan manfaat tabungan mudharabah dapat dilihat dari kepentingan bank dan juga kepentingan nasabah. Dari kepentingan bank antara lain :

a. Sumber pendanaan bank baik.

b. Salah satu sumber pendapatan

Sedangkan dari kepentingan nasabah antara lain :

a. Kemudahan dalam pengelolaan likuiditas baik dalam hal penyetoran, penarikan,

b. transfer, dan pembayaran transaksi yang fleksibel.

c. Dapat memperoleh bonus atau bagi hasil.

\section{Sistem Tabungan Mudharabah}

Ali dalam (Purwaningsih 2016), Sistem perbankan syariah dalam mengaplikasikan akad mudharabah dalam produk tabungan sebagai berikut

a. Di dalam praktik perjanjian dilaksanakan dalam bentuk perjanjian baku. Hal ini bersifat membatasi atas kebersihan kontrak. Adanya pembatasan dimaksud, berkaitan dengan kepentingan umum agar perjanjian baku itu diatur dalam undang-undang atau setidaktidaknya diawasi oleh pihak Dewan Pengawas Syariah Nasional.

b. Bentuk akad produk tabungan mudharabah di bank syariah dimaksud, dituangkan dalam bentuk perjanjian tertulis yang disebut perjanjian bagi hasil.

c. Dalam perjanjian tertulis akad perjanjian tabungan mudharabah disebutkan nisbah bagi hasil pemilik dana dan pengelola dana. Nisbah bagi hasil ini berlaku sampai berakhirnya perjanjian. Perjanjian ini mengikat dan merupakan satu kesatuan yang tidak dapat dipisahkan dengan syarat-syarat dan ketentuan umum.

d. Pelaksanaan akad tabungan mudharabah terjadi apabila ada calon nasabah yang akan menabung atau meminjam modal dari bank syariah. Dalam akad perjanjian tersebut sebelum ditandatangani oleh calon nasabah, terlebih dahulu mempelajari dan apabila calon nasabah menyetujui perjanjian dimaksud, maka calon nasabah menandatangani perjanjian.

\section{Ketentuan Umum Tabungan Mudharabah}

Beberapa ketentuan umum tabungan mudharabah sebagai berikut : a. Dalam transaksi ini, nasabah bertindak sebagai shahibul maal atau pemilik dana, dan bank bertindak sebagai mudharib atau pengelola dana.

b. Dalam kapasitas sebagai mudharib, bank dapat melakukan berbagai macam usaha yang tidak bertentangan dengan prinsip syariah dan mengembangkannya, termasuk didalamnya mudharabah dengan pihak lain.

c. Modal harus dinyatakan dengan jumlahnya, dalam bentuk tunai dan bukan piutang.

d. Pembagian keuntungan harus dinyatakan dalam bentuk nisbahdan dituangkan dalam bentuk akadpembukaan rekening.

e. Bank sebagai mudharib menutup biaya operasioanal tabungan dengan menggunakan nisbah keuntungan yang menjadi haknya.

f. Bank tidak diperkenankan mengurangi nisbah keuntungan nasabah tanpa persetujuan yag bersangkutan (Khaddafi, 2016).

\section{Landasan Hukum Tabungan Mudharabah}

Secara umum, landasan hukum dari tabungan mudharabah bercermin dari landasan dasar syariah al-mudharabah, yaitu Al-Qur'an dan Hadits.

Firman Allah SWT dalam QS. AlMuzammil: 20, (Zamzami, 2017).

“.......dan orang- orang yang berjalan di muka bumi mencari sebagian karunia Allah......".

Yang menjadi wajhud-dilalah atau argumendari surah Al-Muzammil: 20 adalah adanya kata yadhribun yang sama dengan akar kata mudharabah yang berarti melakukan suatu perjalanan usaha.

Berdasarkan hadits yang diriwayatkan oleh Thabrani, Rasulullah SAW bersabda:

"Diriwayatkan dari Ibnu Abbas bahwa Sayyidina Abbas bin Abdul Muthalib jika memberikan dana ke mitra usahanya secara mudharabah ia mensyaratkan agar dananya tidak dibawa mengarungi lautan, menuruni lembah yang berbahaya atau membeli ternak. Jika menyalahi peraturan tersebut, yang bersangkutan bertanggung jawab atas dana tersebut. Disampaikanlah syaratsyarat tersebut kepada Rasulullah SAW dan Rasulullah pun membolehkannya".

\section{Dana dari Masyarakat Luas (Dana Pihak Ketiga)}

Sebagai lembaga intermediasi keuangan, bank memiliki kedudukan ditengah masyarakat yaitu menghimpun dana dan menyalurkan kembali dana tersebut. Untuk itu, bank harus selalu meningkatkan pelayanannya agar mendapat kepercayaan dari masyarakat sehingga sumber dana dari masyarakat dapat ditarik dengan mudah. Dana dari masyarakat merupakan sumber dana terbesar yang dimiliki oleh bank.

Sumber dana ini merupakan sumber dana terpenting dalam kegiatan operasi suatu bank dan merupakan ukuran keberhasilan bank jika mampu membiayai operasinya dari sumber dana ini. 
Pentingnya sumber dana dari masyarakat luas disebabkan sumber dana dari masyarakat merupakan sumber dana yang paling utama bagi bank. Sumber dana yang disebut juga dengan "Dana Pihak Ketiga" ini disamping mudah mencarinya juga tersedia banyak di masyarakat. Untuk memperoleh sumber dana dari masyarakat luas, bank dapat menawarkan berbagai jenis simpanan. Pembagian jenis simpanan kedalam beberapa jenis dimaksudkan agar para nasabah mempunyai banyak pilihan sesuai dengan tujuannya masing-masing.

Pencarian dana dari sumber ini relatif paling mudah jika dibandingkan dengan sumber lainnya dan pencarian dana dari sumber dana ini paling dominan, asalkan bank dapat memberikan bunga dan fasilitas menarik lainnya. Dana-dana yang dihimpun dari masyarakat ternyata merupakan sumber dana terbesar yang paling diandalkan oleh bank (bisa mencapai $80 \%-90 \%$ dari seluruh dana yang dikelola oleh bank). Akan tetapi pencarian sumber dana dari sumber ini relatif lebih mahal jika dibandingkan dari dana sendiri. Dana Pihak Ketiga adalah dana yang diperoleh dari masyarakat, dalam arti masyarakat sebagai individu, perusahaan, pemerintah, rumah tangga, koperasi, yayasan, dan lain-lain baik dalam mata uang rupiah maupun dalam valuta asing. Pada sebagian besar atau setiap bank, dana masyarakat ini umumnya merupakan dana terbesar yang dimiliki. Hal ini sesuai denganfungsi bank sebagai penghimpun dana dari masyarakat.

Dana-dana yang dihimpun dari masyarakat (Dana Pihak Ketiga) ternyata merupakan sumber dana terbesar yang paling diandalkan oleh bank (bisa mencapai $80 \%$ - 90\% dari seluruh dana yang dikelola oleh bank). Menurut Surat Edaran Bank Indonesia No. 6/23/DPNP tanggal 31 Mei 2004 dana yang dipercayakan oleh masyarakat kepada bank dapat berupa giro, tabungan, dan deposito. Kegiatan bank setelah menghimpun dana dari masyarakat luas dalam bentuk simpanan giro, tabungan, dan deposito adalah menyalurkan kembali dana tersebut kepada masyarakat yang membutuhkannya. Kegiatan penyaluran dana ini dikenal juga dengan istilah alokasi dana. Pengalokasian dana dapat diwujudkan dalam bentuk pinjaman atau lebih dikenal dengan kredit. Pemberian kredit merupakan aktivitas bank yang paling utama dalam menghasilkan keuntungan. Dana pihak ketiga adalah berupa penyimpanan sejumlah uang dibank dalam bentuk Giro, Tabungan, Deposito.Simpanan ini dilakukan dengan kesepakatan atau perjanjian antara pihak nasabah dengan bank. Kegiatan usaha bank yang dapat dilakukan berdasarkan UU No. 10 Tahun 1998 tentang perbankan, salah satunya adalah: Menghimpun dana dari masyarakat. Penghimpunan atau mobilisasi dana dapat melalui sarana tabungan, deposito berjangka dan giro (Pratiwi, 2014).

\section{Tingkat Bagi Hasil \\ Pengertian Bagi Hasil}

Sistem bagi hasil merupakan sistem dimana dilakukannya perjanjian atau ikatan bersama di dalam melakukan kegiatan usaha. Di dalam usaha tersebut diperjanjikan adanya pembagian hasil atas keuntungan yang akan didapat antara kedua belah pihak atau lebih. Pembagian hasil keuntungan antara pihak yang melakukan kontrak ditentukan berdasarkan kesepakatan mengenai nisbah bagi hasil pada kontrak, yang ditentukan di muka (Wulansari, 2012).

\section{Metode Perhitungan Bagi Hasil}

Cara perhitungan bagi hasil terdapat dua mekanisme yaitu: profit sharing dan revenue sharing :

\section{a. Profit Sharing}

Perhitungan bagi hasil yang didasarkan kepada hasil net (bersih) dari total pendapatan setelah dikurangi biaya- biaya yang dikeluarkan untuk memperoleh pendapatan tersebut.

\section{b. Revenue Sharing}

Perhitungan bagi hasil didasarkan kepada total pendapatan yang diterima sebelum dikurangi dengan biaya- biaya yang telah dikeluarkan untuk pendapatan- pendapatan tersebut.

Pendapatan- pendapatan yang dihasilkan dari kontrak pembiayaan, setelah dikurangi dengan biaya- biaya operasional, harus dibagi atau didistribusikan antara bank dengan para penyandang dana, yaitu nasabah investasi, para penabung, dan para pemegang saham sesuai dengan nisbah bagi hasil yang diperjanjikan.

\section{Teori Bagi Hasil}

Nugraha dalam (Wulansari, 2012) menjelaskan tingkat bagi hasil yang diberikan oleh bank syariah akan berpengaruh terhadap jumlah tabungan mudharabah. Artinya, jika tingkat bagi hasil yang diberikan bank syariah kepada nasabah lebih tinggi, maka jumlah bagi hasil yang diterima bank akan bertambah dan meningkat. Hal ini akan menyebabkan jumlah tabungan mudharabah yang disalurkan di bank syariah akan lebih besar dan mengalami peningkatan.

\section{BI Rate}

\section{Pengertian BI Rate}

Bunga diartikan sebagai "buah" dari modal yang digunakan atau dipinjamkan. Secara konsep bunga adalah penambahan, perkembangan, peningkatan dan pembesaran yang diterima pemberi pinjaman dari peminjam dari jumlah pinjaman pokok sebagai imbalan karena menangguhkan atau berpisah dari sebagian modalnya selama periode waktu tertentu. Dimana ketika seseorang meminjamkan modalnya dia mengharapkan akan adanya imbalan tertentu sebagai kompensasinya (Wulansari, 2012).

Bunga bank diartikan sebagai balas jasa yang diberikan oleh bank berdasarkan prinsip konvensional kepada nasabah yang membeli atau menjual produknya. Bunga juga dapat diartikan sebagai harga yang harus dibayar kepada nasabah yang memiliki simpanan dengan 
yang harus dibayar oleh nasabah yang memperoleh pinjaman kepada bank (Dabukke, 2017).

Secara leksikal, bunga sebagai terjemahan dari kata interest. Secara istilah sebagaimana diungkapkan dalam suatu kamus dinyatakan, bahwa "interest is a charge for a financial loan, usually a percentage of the amount loaned". Bunga adalah tanggungan pada pinjaman uang, yang biasanya dinyatakan dengan presentase dari uang yang dipinjamkan.

Suku bunga bank konvensional dijadikan salah satu variabel dikarenakan kenaikan dan penurunan suku bunga akan memberikan dampak pada bank syariah yaitu displaced commercial risk, yang merupakan resiko perpindahan dana dari perbankan syariah ke perbankan konvensional dikarenakan tingkat keuntungan yang didapatkan lebih tinggi. sebagaimana disebutkan dalam penelitian (Rahmawati, 2017).

\section{Perbedaan Bagi Hasil dan Bunga}

Sistem bunga dan sistem bagi hasil pada dasarnya sama- sama memberikan keuntungan bagi pemilik dana, namum keduanya mempunyai perbedaan yang sangat nyata.

\section{Penelitian Sebelumnya}

Terdapat beberapa penelitian terdahulu yang peneliti utarakan dan yang mendukung penelitian ini yaitu penelitian yang dilakukan oleh :

Pertama, Wulansari (2015) dengan judul penelitian "Pengaruh Bagi Hasil dan Suku Bunga Terhadap Jumlah Deposito Mudharabah" hasil penelitianya adalah pada pengujian hipotesis secara simultan pada penelitian ini menujukan hasil yang signifikan dan positif terhadap jumlah deposito mudharabah. Bagi hasil deposito 1 bulan, 3 bulan, 6 bulan, dan 12 bulan sebagai salah satu variabel yang memiliki pengaruh yang negatif terhadap jumlah deposito mudharabah.

Kedua, Sudirman (2016) dengan judul penelitian "pengaruh tingkat suku bunga deposito bank konvensional, bagi hasil, dan likuiditas terhadap deposito mudharabah pada bank syariah di Indonesia" menemukan bahwa tingkat suku bunga, bagi hasil, dan likuiditas secara simultan berpengaruh signifikan terhadap deposito. Dan secara parsial variabel tingkat suku bunga berpengaruh signifikan terhadap variabel deposito, sedangkan variabel bagi hasil dan likuiditas tidak perpengaruh signifikan terhadap variabel deposito .

Ketiga, penelitian yang dilakukan oleh Haroon dan Ahmad (2000) yang meneliti hubungan lansung tingkat bunga bank konvensional dengan simpanan di bank syariah. Hasil penelitian ini menunjukkan bahwa tingkat keuntungan di bank syariah berhubungan positif dengan simpanan bank syariah, dimana saat terjadi peningkatan tingkat keuntungan di bank syariah akan mendorong peningkatan total simpanannya. Hubungan antara tingkat bunga di bank konvensional dengan simpanan di bank syariah adalah negatif, dimana apabila terjadi peningkatan tingkat suku bunga, maka simpanan di bank syariah akan menurun.

Keempat, Pratiwi (2014) meneliti pengaruh tingkat bagi hasil terhadap jumlah tabungan mudharabah pada perbankan syariah di Indonesia. hasil penelitiannya menunjukkan bahwa bagi hasil berpengaruh positif dan signifikan terhadap tabungan mudharabah pada bank syariah.

Kelima, Reswari (2010) meneliti pengaruh tingkat suku bunga, jumlah bagi hasil dan LQ 45 terhadap simpanan mudharabah pada bank syariah di Indonesia. Hasil penelitian diketahui bahwa variabel tingkat suku bunga (BI rate) tidak berpengaruh terhadap simpanan mudharabah. Variabel jumlah bagi hasil berpengaruh positif terhadap simpanan mudharabah, sedangkan variabel LQ45 juga berpengaruh positif terhadap simpanan mudharabah bank syariah.

\section{Kerangka Konseptual}

Kerangka konseptual merupakan sintesa dari serangkaian teori yang tertuang dalam tinjauan pustaka, yang pada dasarnya merupakan gambaran sistematis dari kinerja teori dalam memberikan solusi atau alternatif solusi dari serangkaian masalah yang ditetapkan.Kerangka konseptual dapat disajikan dalam bentuk bagan, deskripsi kualitatif, dan atau gabungan keduanya (Zamzami, 2017).

1. Hubungan Tingkat Bagi Hasil dengan Jumlah Tabungan Mudharabah Pada Bank Syariah

Sistem bagi hasil merupakan sistem dimana dilakukannya perjanjian atau ikatan bersama di dalam melakukan kegiatan usaha. Di dalam usaha tersebut diperjanjikan adanya pembagian hasil atas keuntungan yang akan didapat antara kedua belah pihak atau lebih. Pembagian hasil keuntungan antara pihak yang melakukan kontrak ditentukan berdasarkan kesepakatan mengenai nisbah bagi hasil pada kontrak, yang ditentukan di muka (Wulansari, 2012).

Tingkat bagi hasil akan mempunyai hubungan yang positif terhadap jumlah Tabungan Mudharabah bank syariah. Asumsinya, bahwa para nasabah menyimpan uangnya di bank konvensional dengan motif profit maximization. Jika manajemen bank syariah juga mempunyai asumsi yang sama, maka bank syariah akan berusaha untuk memberikan tingkat bagi hasil minimal sama atau bahkan lebih tinggi dari pada yang diinfokan oleh bank konvensional. Sebagaimana dalam penelitian terdahulu yang dilakukan oleh Masturoh (2011) menyatakan bahwa return bagi hasil berpengaruh secara signifikan terhadap perkembangan dana pihak ketiga mudharabah. Sedangkan Rizqiana (2010) menyimpulkan bahwa adanya pengaruh antara bagi hasil terhadap jumlah dana deposan menunjukkan bahwa semakin besar bagi hasil, maka semakin besar kemungkinan bank memperoleh modal berupa dana pihak ketiga yaitu deposito syariah. Begitu juga sebaliknya, apabila bagi hasil yang diperoleh sedikit, 
maka kemungkinan bank memperoleh deposito syariah semakin sedikit.Dari semua penelitian terdahulu menunjukkan bahwa adanya pengaruh antara bagi hasil dengan DPK baik tabungan maupun deposito. Semakin besar bagi hasil, maka semakin besar kemungkinan bank memperoleh modal berupa dana pihak ketiga yaitu tabungan maupun deposito syariah. Begitu juga sebaliknya, apabila bagi hasil yang diperoleh sedikit, maka kemungkinan bank memperoleh deposito syariah semakin sedikit.

2. Hubungan BI Rate dengan Jumlah Tabungan Mudharabah Pada Bank Syariah

$\mathrm{BI}$ rate merupakan harga dari penggunaan uang atau bisa juga dipandang sebagai sewa atas penggunaan uang untuk jangka waktu tertentu seperti halnya dengan barang-barang lain. Pada bank umum kebijakan bunga akan sangat tergantung dengan kebijakan bunga dari Bank Sentral. Apabila $\mathrm{BI}$ rate pada bank konvensional lebih tinggi dibandingkan dengan tingkat bagi hasil yang ditawarkan bank syariah, maka tidak menutup kemungkinan nasabah yang semula merupakan nasabah bank syariah akan beralih menjadi nasabah bank konvensional. Sebaliknya, jika tingkat bagi hasil yang ditawarkan bank syariah lebih tinggi dibandingkan BI rate di bank konvensional, maka tidak menutup kemungkinan nasabah yang semula merupakan nasabah bank konvensional akan beralih menjadi nasabah bank syariah.

Tingkat bunga merupakan salah satu pertimbangan utama seseorang dalam memutuskan untuk menabung.Tabungan merupakan fungsi dari tingkat bunga. BI rate yang tinggi akan mendorong seseorang untuk menabung dan mengorbankan konsumsi di masa yang akan datang.

Tingginya minat masyarakat untuk menabung biasanya dipengaruhi oleh BI rate yang tinggi. Hubungan yang positif antara BI rate dengan tingkat tabungan ini menunjukkan bahwa pada umumnya para penabung bermotif pada keuntungan atau "profit motive"

Hubungan negatif BI rate pada bank konvensional terhadap tabungan mudharabah karena dengan meningkatnya suku bunga akan menyebabkan peningkatan risiko displacement fund (pengalihan dana dari bank syariah ke bank konvensional) yang akan dihadapi bank syariah. Hal ini tentunya akan membuat jumlah dana pihak ketiga yang dihimpun oleh bank syariah menurun.

Kerangka konseptual dalam penelitian ini dapat digambarkan dalam gambar 2.1 :

Variabel Independen.

\section{Hipotesis Penelitian}

Berdasarkan teori dan kerangka konseptual tersebut, maka hipotesis di bawah ini pada dasarnya merupakan jawaban sementara terhadap suatu masalah yang harus dibuktikan kebenarannya, adapun hipotesis yang dirumuskan dalam penulisan ini adalah sebagai berikut:

$\mathrm{H}_{1}$ : Tingkat bagi hasil berpengaruh terhadap jumlah tabungan mudharabah pada Bank Syariah

$\mathrm{H}_{2}$ : $\quad$ BI rate berpengaruh terhadap jumlah tabungan mudharabah pada Bank Syariah

\section{METODE PENELITIAN}

\section{Lokasi dan Objek Penelitian}

Penelitian ini mengambil lokasi pada Bank Umum Syariah (BUS) yang terdaftar di Bursa Efek Indonesia.Objek penelitian pada laporan keuangan tahunan Bank Umum Syariah (BUS).Serta data BI Rate yang dipublikasikan oleh Bank Indonesia periode 2013-2018 melalui website resmi Bank Indonesia atau website resmi lainya.

\section{Populasi dan Sampel Populasi}

Populasi adalah sekumpulan objek yang lengkap yang terdiri atas orang, kejadian, atau benda yang memiliki karakteristik yang umum dalam penelitian. Menurut Sugiono (2014), populasi merupakan wilayah generalisasi yang terdiri atas objek atau subjek yang mempunyai kualitas dan karakteristik tertentu yang ditetapkan oleh peneliti untuk dipelajari dan kemudian ditarik kesimpulannya.

Populasi dalam penelitian ini adalah seluruh Bank Umum Syariah yang terdaftar di Bursa Efek Indonesia (BEI) periode tahun 2013 sampai dengan 2018 yang berjumlah 12 perbankan.

\section{Sampel}

Sampel dalam penelitian ini adalah seluruh Bank Umum Syariah yang terdaftar di Bursa Efek Indonesia (BEI) pada tahun 2013 sampai dengan 2018. Metode pemilihan sampel yang digunakan dalam penelitian ini adalah sampling jenuh atau sensus, yaitu teknik penentuan sampel dengan menggunakan semua anggota populasi. Dalam penelitian ini karena jumlah populasinya sedikit (terbatas) sehingga tidak memungkinkan untuk menggunakan sampel, maka peneliti mengambil jumlah sampel sama dengan jumlah populasi atau disebut dengan sensus yaitu Bank Umum Syariah yang terdaftar di Bursa Efek Indonesia (BEI) sebanyak 12 bank. Berikut adalah daftar Bank Umum Syariah di Indonesia :

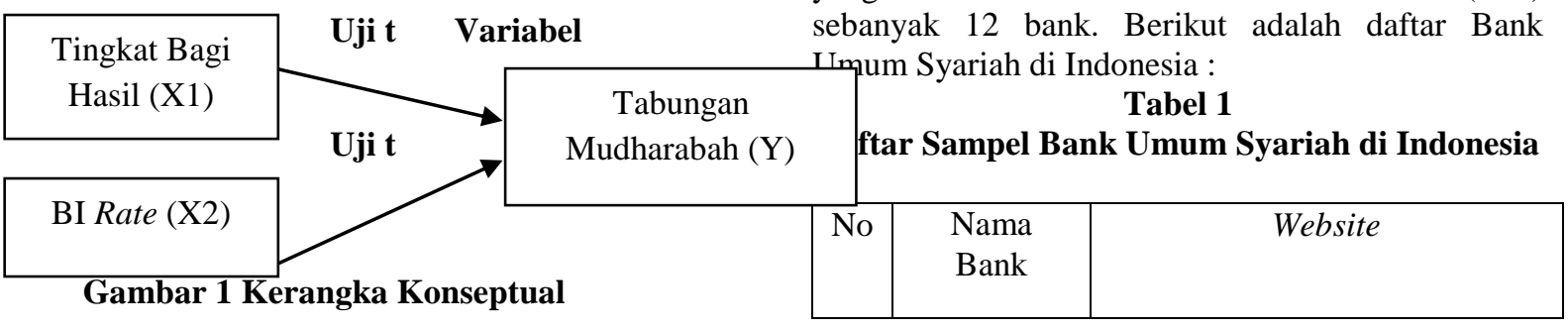




\begin{tabular}{|c|c|c|}
\hline 1 & $\begin{array}{l}\text { PT. Bank } \\
\text { Syariah } \\
\text { Mandiri }\end{array}$ & www.syariahmandiri.co.id \\
\hline 2 & $\begin{array}{l}\text { PT. Bank } \\
\text { Syariah } \\
\text { Muamalat } \\
\text { Indonesia }\end{array}$ & www.muamalatbank.co.id \\
\hline 3 & $\begin{array}{l}\text { PT. Bank } \\
\text { Syariah } \\
\text { BNI }\end{array}$ & www.bnisyariah.co.id \\
\hline 4 & $\begin{array}{l}\text { PT. Bank } \\
\text { Syariah } \\
\text { BRI }\end{array}$ & www.brisyariah.co.id \\
\hline 5 & $\begin{array}{l}\text { PT. Bank } \\
\text { Syariah } \\
\text { Mega } \\
\text { Indonesia }\end{array}$ & www.bmsi.co.id \\
\hline 6 & $\begin{array}{l}\text { PT. Bank } \\
\text { Jabar dan } \\
\text { Banten } \\
\text { Syariah }\end{array}$ & www.bjbsyariah.co.id \\
\hline 7 & $\begin{array}{l}\text { PT. Bank } \\
\text { Panin } \\
\text { Syariah }\end{array}$ & www.paninbanksyariah.co.id \\
\hline 8 & $\begin{array}{l}\text { PT. Bank } \\
\text { Syariah } \\
\text { Bukopin }\end{array}$ & www.syariahbukopin.co.id \\
\hline 9 & $\begin{array}{l}\text { PT. Bank } \\
\text { BCA } \\
\text { Syariah }\end{array}$ & www.bcasyariah.co.id \\
\hline 10 & $\begin{array}{l}\text { PT. } \\
\text { Maybank } \\
\text { Syariah } \\
\text { Indonesia }\end{array}$ & www.maybanksyariah.co.id \\
\hline 11 & $\begin{array}{l}\text { PT. BPTN } \\
\text { Syariah }\end{array}$ & www.btpnsyariah.co.id \\
\hline 12 & $\begin{array}{l}\text { Bank } \\
\text { Victoria } \\
\text { Syariah }\end{array}$ & www.bankvictoriasyariah.co.id \\
\hline
\end{tabular}

Sumber :www.ojk.go.id, data diolah (2019)

Berdasarkan sampel perusahaan yang digunakan dalam penelitian ini adalah 12 perbankan syariah dan lama penelitian dilakukan 6 tahun yaitu 2013 sampai 2018, sehingga jumlah pengamatan dalam penelitian yaitu 72 pengamatan $(12 \times 6=72)$.

\section{Metode Pengumpulan Data}

Penelitian ini menggunakan data sekunder, yaitu data berupa laporan keuangan tahunan dan data dari statistik Perbankan Syariah
Indonesia yang telah dipublikasikan oleh Bank Indonesia dan Otoritas Jasa Keuangan (OJK). Data tersebut terdiri dari laporan persentase tabungan mudharabah, tingkat bagi hasil, BI rate periode 2013 sampai dengan 2018 yang dipublikasikan. Metode pengumpulan data yang digunakan dalam penelitian ini adalah metode penelitian kepustakaan yaitu pengumpulan data dan informasi dengan mengolah literatur, buku, artikel, jurnal, hasil penelitian terdahulu maupun media tertulis lainnya yang berhubungan dengan topik yang dibahas dalam penelitian ini. Sebagian besar literatur yang digunakan dalam penelitian ini merupakan jurnal-jurnal penelitian, makalah penelitian terdahulu, buku dan internet research yang berhubungan dengan tema penelitian.

\section{Definisi Operasional Variabel}

1. Variabel Dependen (Y)

Variabel dependen dalam penelitian ini

adalah tabungan mudharabah.Tabungan Mudharabah adalah simpanan yang penarikannya dapat dilakukan menurut syarat-syarat tertentu yang disepakati, tetapi tidak dapat ditarik dengan cek, bilyet giro, dan/atau alat lainnya yang dipersamakan dengan itu (zamzami, 2017).

Adapun data untuk tabungan mudharabah didapat dari laporan keuangan tahunan Bank Umum Syariah (BUS) yang terdaftar di Bursa Efek Indonesia (BEI) dalam bentuk miliyaran rupiah. Data yang akan digunakan adalah data periode tahun 2013 sampai dengan 2018.Tabungan Mudharabah dalam penelitian ini diukur dari jumlah tabungan yang tersimpan pada masing-masing Bank Umum Syariah (BUS) yang menjadi sampel penelitian.

2. Variabel Independen $(\mathrm{X})$

1. Tingkat Bagi Hasil ( $\left.\mathrm{X}_{1}\right)$

Sistem bagi hasil merupakan sistem dimana dilakukannya perjanjian atau ikatan bersama di dalam melakukan kegiatan usaha. Di dalam usaha tersebut diperjanjikan adanya pembagian hasil atas keuntungan yang akan didapat antara kedua belah pihak atau lebih. Pembagian hasil keuntungan antara pihak yang melakukan kontrak ditentukan berdasarkan kesepakatan mengenai nisbah bagi hasil pada kontrak, yang ditentukan di muka (Wulansari, 2012).

Adapun sumber data Bagi Hasil diperoleh dari situs Bank Indonesia (www.bi.go.id) statistik perbankan syariah Indonesia dalam bentuk persentase (\%). Data yang akan digunakan adalah data periode tahun 2013 sampai dengan 2018. Rasio ini mengacu pada (Wahyuningtyas, 2015) dapat dihitung dengan rumus :

Tingkat Bagi Hasil = Bagi Hasil yang diterima Nasabah/ Jumlah Pembiayaan Bagi Hasil x 100\%

2. BI Rate $\left(\mathrm{X}_{2}\right)$

Adapun sumber data BI Rate diperoleh dari situs Bank Indonesia (www.bi.go.id) dalam 
bentuk persentase (\%). Data yang akan digunakan adalah data periode tahun 2013 sampai dengan 2018.BI rate dapat di ketahui dengan melihat besarnya Tingkat Suku Bunga Bank Indonesia (BI Rate) dalam laporan yang dipublikasikan oleh Bank Indonesia setiap bulannya.

Berikut ini disajikan tabel definisi operasional variabel beserta pengukuran masingmasing variabel :

\section{Uji Asumsi Klasik}

Pengujian regresi linear dapat dilakukan setelah model pada penelitian ini memenuhi syaratsyarat yaitu lolos dari uji asumsi klasik. Pengujian asumsi klasik diperlukan untuk mendeteksi ada/tidaknya penyimpangan asumsi klasik atas persamaan rgresi berganda yang digunakan. Pengujian ini terdiri atas uji normalitas, multikolonieritas, autokorelasi dan heteroskedastisitas.

\section{Uji Normalitas}

Uji normalitas bertujuan untuk menguji apakah dalam model regresi variabel pengganggu atau residual memiliki distribusi normal (Ghozali, 2013).Seperti yang kita ketahui bahwa uji t dan uji $\mathrm{F}$ mengasumsikan bahwa nilai residual mengikuti distribusi normal.Jika asumsi ini dilanggar maka uji statistik menjadi tidak valid untuk jumlah sampel kecil. Ada dua cara untuk mendeteksi apakah residual berdistribusi normal atau tidak yaitu dengan analisis grafik dan uji statistik.

Dasar pengambilan keputusan untuk uji normalitas data adalah (Ghozali, 2013) :

1. Jika data menyebar di sekitar garis diagonal dan mengikuti arah garis diagonal atau grafik histogramnya menunjukkan pola distribusi normal, dan pada tabel kolmogorov-smirnov signifikansinya lebih dari $5 \%(>0,05)$ maka model regresi memenuhi asumsi normalitas.

2. Jika data menyebar jauh dari diagonal dan/atau tidak mengikuti arah garis diagonal atau grafik histogramnya tidak menunjukkan pola distribusi normal dan pada tabel kolmogorovsmirnov signifikansinya kurang dari 5\% (< $0,05)$ maka model regresi tidak memenuhi asumsi klasik.

\section{Uji Multikolinieritas}

Uji multikolinieritas bertujuan untuk menguji apakah model regresi ditemukan adanya korelasi antar variabel bebas (independen). Model regresi yang baik seharusnya tidak terjadi korelasi diantara variabel independen (Ghozali, 2013). Salah satu untuk mengetahui ada/tidaknya multikolinieritas ini adalah dengan menggunakan Variance Inflation Factor (VIF) dan Tolerance. Kedua ukuran ini menunjukkan setiap variabel independen manakah yang dijelaskan oleh variabel independen lainnya. Tolerance mengukur variabilitas variabel independen yang terpilih dan tidak dijelaskan oleh variabel independen lainnya. Jadi nilai tolerance yang rendah sama dengan nilai
VIF tinggi (karena VIF $=1 /$ Tolerance). Kriteria pengambilan keputusan dengan nilai tolerance dan VIF adalah sebagai berikut :

1. Jika nilai tolerance 0,10 atau nilai VIF 10 , berarti tidak terjadi multikolonieritas.

2. Jika nilai tolerance 0,10 atau nilai VIF 10 , berarti terjadi multikolonieritas.

\section{Uji Autokorelasi}

Uji autokorelasi bertujuan menguji apakah dalam model regresi linear terdapat korelasi antara kesalahan penganggu pada periode $t$ dengan kesalahan penganggu pada periode t-1 (Ghozali, 2013). Jika terjadi korelasi, maka dinamakan ada masalah autokorelasi. Autokorelasi muncul karena observasi yang berurutan sepanjang tahun yang berkaitan satu dengan yang lainnya, hal ini sering ditemukan pada time series. Pada data cross section, masalah autokorelasi relatif tidak terjadi (Ghozali, 2013). Pengambilan keputusan ada tidaknya autokorelasi adalah sebagai berikut:

1) Bila nilai Durbin-Watson (DW) terletak antara batas atas atau Upper Bound (DU) dan 4-DU, maka koefisien autokorelasi sama dengan nol berarti tidak ada autokorelasi.

2) Bila nilai DW lebih rendah dari pada batas bawah atau Lower Bound (DL), maka koefisien autokorelasi lebih besar dari pada nol, berarti ada autokorelasi positif.

3) Bila nilai DW lebih besar dari pada (4DL), maka koefisien autokorelasi lebih kecil dari pada nol, berarti ada autokorelasi negatif.

4) Bila nilai DW terletak diantara batas atas (DU) dan batas bawah (DL) atau DW terletak antara (4-DU) dan (4-DL), maka hasilnya tidak dapat disimpulkan.

\section{Uji Heteroskedasitas}

Uji heteroskedastisitas bertujuan menguji apakah dalam model regresi terjadi ketidaksamaan variance dari residual satu pengamatan ke pengamatan yang lain. Jika variance dari residual satu pengamatan ke pengamatan lain tetap, maka disebut homoskedastisitas dan jika berbeda disebut heteroskedastisitas. Model regresi yang baik adalah yang homoskesdatisitas atau tidak terjadi heteroskesdatisitas.

Uji heteroskedastisitas memiliki cara untuk mendeteksi ada atau tidaknya heterokedastisitas dengan cara melihat grafik plot antara nilai prediksi variabel bebas, yaitu ZPRED dengan residualnya SRESID. Dasar analisis dalam grafik uji heterokedastisitas adalah yang pertama dengan melihat jika ada pola tertentu, seperti titik-titik yang ada membentuk pola tertentu yang teratur (bergelombang, melebar kemudian menyempit), maka mengindikasikan telah terjadi heterokedastisitas. Dasar analisis yang kedua adalah jika tidak ada pola yang jelas, serta titik-titik menyebar di atas dan di bawah angka 0 (nol) pada sumbu Y, maka tidak terjadi heterokedastisitas (Gujarati, 2012) .

\section{Metode Analisis Data}


Statistik deskriptif memberikan gambaran atau deskripsi umum dari variabel penelitian, yaitu gambaran suatu data yang dilihat dari nilai rata-rata (mean), standar deviasi, varian, maksimum, minimum, sum, range, kurtoris, dan skewness (kemencengan distribusi) (Ghozali, 2013).

Penelitian ini menggunakan alat analisis regresi berganda (multipleregression) untuk menguji pengaruh antara variabel dependen dengan variabel independen. Tujuan analisis regresi berganda ialah menggunakan nilai-nilai variabel independen yang diketahui, untuk maramalkan nilai variabel dependen. Persamaan regresi berganda dirumuskan :

Dimana :

$$
\gamma=\alpha+\beta_{1} \mathrm{X}_{1}+\beta_{2} \mathrm{X}_{2}+\varepsilon
$$

$$
\begin{gathered}
\gamma: \text { Tabungan Mudharabah } \\
\alpha: \text { Konstanta } \\
\beta \text { : Koefisien regresi } \\
\mathrm{X}_{1}: \text { Tingkat Bagi Hasil } \\
\mathrm{X}_{2}: \text { BI Rate }
\end{gathered}
$$

\section{Uji Hipotesis}

Pengujian hipotesis adalah suatu prosedur yang dilakukan dengan tujuan memutuskan apakah menerima atau menolak hipotesis mengenai parameter populasi.

\section{Uji Signifikansi Parameter Individual ( Uji Statistik t)}

Uji statistik t digunakan untuk mengetahui pengaruh masing-masing variabel independen terhadap variabel dependen (Ghozali, 2013). Kriteria pengujian atau dasar pengambilan keputusan dalam penelitian ini menggunakan taraf signifikansi 5\% adalah sebagai berikut:

1. Apabila nilai signifikansi $<0,05$, maka Ho akan ditolak atau Ha diterima, artinya semua variabel independen secara parsial berpengaruh terhadap variabel dependen.

2. Apabila nilai signifikansi >0,05, maka Ho akan diterima atau Ha ditolak, artinya semua variabel independen secara parsial tidak berpengaruh terhadap variabel dependen.

\section{Uji Koefisiensi Determinasi (Uji $\mathbf{R}^{\mathbf{2}}$ )}

Koefisien determinasi $\left(\mathrm{R}^{2}\right)$ digunakan untuk menguji goodness-fit dari model regresi. Hasil yang ditunjukkan memberikan gambaran seberapa besar variabel dependen akan mampu dijelaskan oleh variabel independen, sedangkan sisanya dijelaskan oleh variabel lain di luar model. Nilai koefisien determinasi berkisar antara satu dan nol $\left(0<\mathrm{R}^{2}<1\right)$, dimana semakin tinggi $\mathrm{R}^{2}$ suatu regresi atau nilainya mendekati satu, maka hasil regresi tersebut semakin baik. Hal ini berarti variabel-variabel independen memberikan hampir semua informasi yang dibutuhkan untuk memprediksi variasi variabel independen (Ghozali, 2013).

\section{HASIL DAN PEMBAHASAN}

\section{Pengujian Asumsi Klasik Uji Normalitas}

Uji Normalitas bertujuan untuk menguji apakah dalam model regresi variabel dependen dan variabel independen keduanya mempunyai distribusi normal atau tidak. Model regresi yang baik adalah memiliki distribusi normal atau mendekati normal. Adapun pengujian normalitas dengan menggunakan analisis statistik melalui uji Kolmogrov Smirnov (Ks) dengan alat bantu komputer yang menggunakan program SPSS 20.0, dapat terdilihat sebagai berikut:

\section{Tabel 2 Hasil Uji Normalitas}

\begin{tabular}{|l|lr|}
\hline \multicolumn{2}{|c|}{ One-Sample Kolmogorov-Smirnov Test } \\
\hline \multicolumn{2}{|l|}{} & \multicolumn{1}{|c|}{$\begin{array}{c}\text { Standardized } \\
\text { Residual }\end{array}$} \\
\hline $\mathrm{N}$ & Mean & $0 \mathrm{E}-7$ \\
\hline \multirow{2}{*}{$\begin{array}{l}\text { Normal } \\
\text { Parameters }\end{array}$} & $\begin{array}{l}\text { Std. } \\
\text { Deviation }\end{array}$ &, 98581488 \\
\hline \multirow{2}{*}{$\begin{array}{l}\text { Most Extreme } \\
\text { Differences }\end{array}$} & Absolute &, 134 \\
\cline { 2 - 3 } & Positive &,- 115 \\
\cline { 2 - 3 } Negative & 1,140 \\
\hline Kolmogorov-Smirnov Z &, 149 \\
\hline \multicolumn{2}{|l|}{ Asymp. Sig. (2-tailed) } & \\
\hline \multicolumn{2}{|l|}{ a. Test distribution is Normal. } \\
\hline \multicolumn{2}{|l}{ b. Calculated from data. } \\
\hline
\end{tabular}

Sumber : Hasil penelitian, diolah (2019)

Menurut Ghozali (2006:149) mengungkapkan bahwa ketentuan uji Kolmogrov Smirnov (K-s)jika nilai signifikan >0,05 maka distribusi data normal. Berdasarkan hasil out put SPSS 20.0 dari Tabel 4.1 terlihat bahwa nilai Kolmogrov Smirnov (K-s) adalah 1,140 dengan Asymp. Sig. (2-tailed) sebesar 0.149 (>0.05) maka dapat disimpulkan bahwa instrumen dalam penelitian berdistribusi normal.

\section{Uji Autokorelasi}

Uji Autokorelasi yaitu adanya hubungan antara kesalahan pengganggu yang muncul pada data runtut waktu (time series). Dalam penaksiranmodel regresi linier mengandung asumsi bahwa tidak terdapat autokorelasi antara kesalahan pengganggu. Pengujian autokorelasi dapat dilakukan dengan menghitung Durbin-Wetson (d), dengan membandingkan nilai d terhadap dl dan du. Setelah menghitung nilai statistik selanjutnya dibandingkan dengan dari tabel dengan tingkat signifikan $5 \%$. Hasil pengujian autokorelasi dapat dilihat dari tabel berikut :

Tabel 3 Hasil Uji Autokorelasi

\begin{tabular}{|l|c|c|c|c|}
\hline \multicolumn{5}{|c|}{ Model Summary $^{\mathbf{b}}$} \\
\hline $\begin{array}{l}\text { Mod } \\
\text { el }\end{array}$ & $\mathrm{R}$ & R Square & $\begin{array}{c}\text { Adjusted R } \\
\text { Square }\end{array}$ & $\begin{array}{c}\text { Durbin- } \\
\text { Watson }\end{array}$ \\
\hline
\end{tabular}




\begin{tabular}{|l|l|l|l|l|}
\hline & & & & \\
\hline 1 &, $759^{\mathrm{a}}$ &, 576 &, 564 & 1,047 \\
& & & & \\
\hline
\end{tabular}

a. Predictors: (Constant), BI Rate, Tingkat Bagi Hasil

b. Dependent Variable: Tabungan Mudharabah

Sumber : Hasil penelitian, data di olah (2019)

Berdasarkan tabel 4.2 nilai Durbin-Waston

(DW) sebesar 1,047 nilai dl (batas luar) sebesar 1,5611, dan nilai du (batas dalam) sebesar 1.6751 (lihat tabel Durbin-Waston). Nilai Durbin-Waston < (4-du) yaitu $(4-1.6751=2.3249)$ atau $1,5611<$ $1,047<2,3249$, maka tidak ada autokorelasi baik autokorelasi positif maupun autokorelasi negatif

\section{Uji Multikolinieritas}

Uji Multikolinieritas adalah situasi adanya korelasi variabel-variabel bebas diantara satu dengan yang lain.Model regresi berganda harus terbebas dari multikolinieritas untuk satu variabel dependennya.Untuk mendeteksi ada tidaknya multikolinieritas dalam model regresi dapat dilihat dari nilai Tolerance dan Variance Inflation Factor (VIF).pengertian sederhana setiap variabel bebas menjadi variabel terikat dan diregresi terhadap variabel bebas lainnya. Tolerance mengukur variabel bebas yang terpilih yang tidak dapat dijelaskan dalam variabel bebas lainnya. Jika nilai tolerance $<0,10$ atau VIF $>10$ maka terjadi multikolinieritas. Hasil multikolonieritas di uraikan pada Tabel 4.3 berikut ini :

\section{Tabel 4 Uji Multikoleniearitas}

Coefficients $^{\mathrm{a}}$

\begin{tabular}{|l|l|c|c|}
\hline \multirow{2}{*}{\multicolumn{2}{|c|}{ Model }} & \multicolumn{2}{|c|}{ Collinearity Statistics } \\
\cline { 2 - 4 } 1 & Tolerance & VIF \\
\hline \multirow{3}{*}{} & (Constant) & & \\
\cline { 2 - 4 } & Tingkat Bagi Hasil &, 996 & 1,004 \\
\cline { 2 - 4 } & Bi Rate &, 996 & 1,004 \\
\hline
\end{tabular}

a. Dependent Variable: Tabungan Mudharabah

Sumber : Hasil Penelitian 2019 (data diolah)

Hasil perhitungan nilai tolerance menunjukkan tidak ada variabel independen yang memiliki nilai tolerance kurang dari 0,10 yang berarti tidak ada kolerasi antara variabel independen. Hasil perhitungan nilai variance inflation factor (VIF) juga menunjukkan hal yang sama tidak ada satu variabel independen yang memiliki VIF lebih dari 10. Jadi dapat disimpulkan bahwa tidak ada multikolonieritas antara variabel independen dalam model regresi.

\section{Uji Heteroskedastisitas}

Uji heteroskedastisitas bertujuan untuk menguji apakah dalam model regresi terjadi ketidaksamaan variancedari residual satu pengamatan ke pengamatan lain. Jika variance residual satu pengamatan ke pengamatan lain tetap, maka disebut homoskedastisitas atau tidak terjadi heteroskedastisitas. Cara untuk mendeteksi ada tidaknya heteroskedastisitas yaitu dengan melihat grafik plot antara nilai prediksi variabel terikat denga residualnya. Deteksi ada tidaknya heteroskedastisitas dapat dilakukan dengan melihat ada tidaknya pola tertentu pada grafik. Hasil sccatterplotpengujian heteroskedastisitas dengan menggunakan metode grafik dapat dilihat dari Gambar 4.2sebagai berikut:

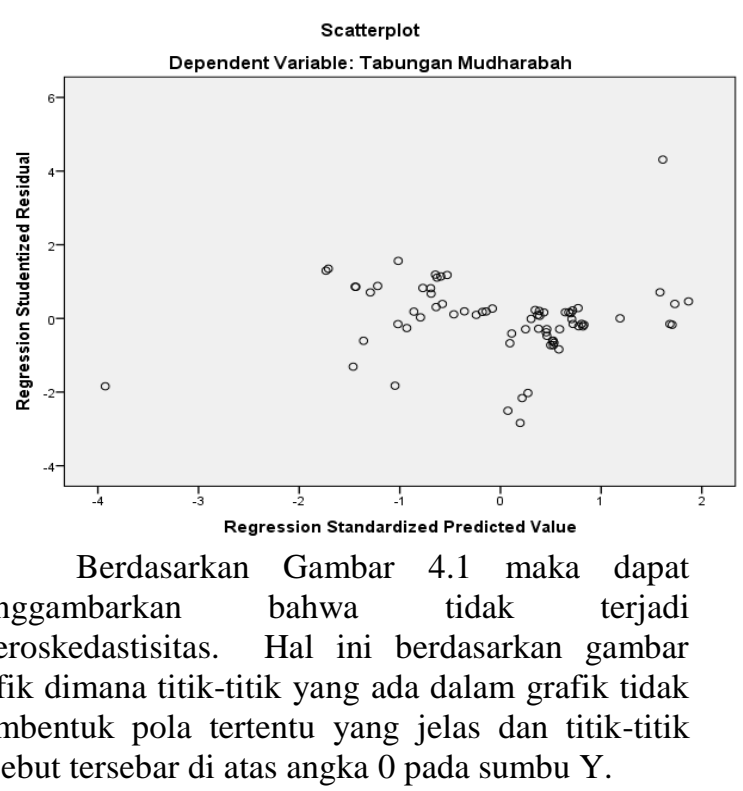

\section{Pengujian Hipotesis}

Uji hipotesis adalah pengujian yang dilakukan oleh peneliti untuk mendapatkan hasil akhir dari penelitian yang telah di utarakan sebelumnya. Analisis yang digunakan untuk menguji hipotesis pada penelitian ini adalah analisis regresi linear berganda (multiple regression analysis) yang bertujuan untuk mengukur kekuatan hubungan dan menunjukkan arah hubungan antara variabel independen terhadap variabel dependen.Dalam uji ini model regresi yang digunakan adalah model regresi linier berganda. Hasil regresi dapat dilihat pada tabel 4.4 berikut :

Tabel 5

Hasil Analisis Regresi Linier Berganda

\begin{tabular}{|l|l|r|r|r|r|}
\hline \multicolumn{5}{|c|}{ Coefficients $^{\text {a }}$} \\
\hline \multicolumn{2}{|c|}{ Model } & \multicolumn{1}{c|}{ B } & t hitung & t Tabel & Sig. \\
\hline 1 & (Constant) & 2,761 &, 671 & &, 504 \\
\cline { 1 - 4 } & Tingkat Bagi Hasil &, 692 & 9,685 & 1,667 &, 000 \\
\cline { 1 - 3 } & Bi Rate &, 120 &, 228 & &, 820 \\
\hline
\end{tabular}


a. Dependent Variable: Tabungan Mudharabah

Sumber : Hasil penelitian, data di olah (2019)

Berdasarkan Tabel 4.4 dapatlah persamaan

regresi berganda sebagai berikut :

$\mathrm{Y}=2,761+0,692 \mathrm{X}_{1}+0,120 \mathrm{X}_{2}+\mathrm{e}$

Dari persamaan regresi linear berganda diatas dapat dijelaskan sebagai berikut:

a. Konstanta sebesar 2,761. Hal ini mengindikasikan bahwa variabel dependen mempunyai nilai 2,761apabila variabel independen dianggap konstan (bernilai nol).

b. Nilai koefisien $\left(b_{1}\right)$ untuk variabeltingkat bagi hasil bernilai positif sebesar 0.692 , hal ini menunjukkan bahwa setiap peningkatan bagi hasil sebesar $1 \%$ maka akan meningkatkan tabungan mudharabah sebesar 69,2\%. Begitu juga sebaliknya terhadap penurunan bagi hasil yang diterima sebesar $1 \%$ maka akan menurunkan tabungan mudharabah sebesar $69,2 \%$.

c. Nilai koefisien $\left(b_{2}\right)$ untuk variabel BI rate bernilai positif sebesar 0,120 , hal ini menunjukkan bahwa setiap peningkatan $\mathrm{Bi}$ ratesebesar $1 \%$ maka akan menaikan tabungan mudharabah sebesar $12 \%$. Begitu juga sebaliknya terhadap penurunan $\mathrm{Bi}$ rateyang diterima sebesar $1 \%$ maka akan menurunkan tabungan mudharabah sebesar $12 \%$.

\section{Hasil Uji Parsial (Uji Statistik t)}

Uji t menunjukkan seberapa jauh pengaruh satu variabel independen secara individual dalam menerangkan variabel dependen. Uji ini dilakukan untuk melihat pengaruh Tingkat Bagi Hasil dan BI Rate Terhadap Besarnya Tabungan Mudharabah Pada Bank Syariah Periode 2013 - 2018.

Pengujian ini dilakukan dengan ketentuan jika $\mathrm{t}$ hitung $>\mathrm{t}$ tabel pada $\alpha=0.05$ maka hipotesis diterima atau dengan kata lain terdapat pengaruh yang signifikan antara satu variabel independen terhadap variabel dependen. Adapun hasil penelitian dapat di lihat pada Tabel 4.5 berikut ini :

Tabel 6 Hasil Uji Parsial

\begin{tabular}{|c|c|c|c|c|}
\hline \multicolumn{5}{|c|}{ Coefficients $^{\mathrm{a}}$} \\
\hline Model & $\mathbf{B}$ & $\mathbf{t}$ hitung & $\mathbf{t}_{\text {Tabel }}$ & Sig. \\
\hline \begin{tabular}{l|l}
1 & (Constant)
\end{tabular} & 2,761 & 671 & \multirow{3}{*}{1,667} &, 504 \\
\hline Tingkat Bagi Hasil & 692 & 9,685 & &, 000 \\
\hline Bi Rate & , 120 & ,228 & & \\
\hline
\end{tabular}

a. Dependent Variable: Tabungan Mudharabah

Sumber : hasil penelitian, diolah (2019)
Nilai $\mathrm{t}$ tabel diperoleh dari degree of freedom(df) untuk uji parsial 2 arah pada sampel 72 df $=\mathrm{N}-\mathrm{k}-1$ yaitu $72-2-1=69$ untuk hipotesis dengan nilai t pada signifikansi5\% atau 0,05, maka nilai $\mathrm{t}_{\text {tabel }}$ yang diperoleh adalah sebesar 1,667.

\section{Pengaruh Tingkat Bagi Hasil Terhadap Tabungan Mudharabah}

Berdasarkan tabel 4.5 hasil uji t untuk tingkat bagi hasil $\left(\mathrm{X}_{1}\right)$ diperoleh angka $\mathrm{t}_{\text {hitung }}$ sebesar 9,685, sementara nilai $\mathrm{t}$ tabel pada $\alpha=0,05$ adalah sebesar 1.667 artinya $t_{\text {hitung }}>t_{\text {tabel }}$ dengan tingkat signifikansi lebih kecil dari 0,05 yaitu 0,000 . Dengan demikian dapat disimpulkan bahwa $\mathrm{H}_{1}$ diterima dan dapat diartikan bahwa secara parsial tingkat bagi hasil berpengaruh positif dan signifikan terhadap tabungan mudharabah.

\section{Pengaruh BI Rate Terhadap Tabungan Mudharabah}

$\mathrm{BI}$ rate $\left(\mathrm{X}_{2}\right)$ diperoleh angka $\mathrm{t}$ hitung 0,228 , sementara nilai $\mathrm{t}$ tabel pada $\alpha=0,05$ adalah sebesar 1.667 artinya $\mathrm{t}$ hitung $<\mathrm{t}$ tabel dengan tingkat signifikansi lebih besar dari 0,05 yaitu 0,820. Dengan demikian dapat disimpulkan bahwa $\mathrm{H}_{2}$ ditolak dan dapat diartikan bahwa secara parsial BI rate tidak berpengaruh terhadap tabungan mudharabah.

\section{Hasil Uji Simultan}

Uji ini dilakukan dengan menggunakan uji signifikan simultan yaitu uji f, untuk menunjukkan apakah variabel bebas (independen) secara bersamasama mempunyai pengaruh terhadap variabel terikat (dependen).

Tabel 7 Hasil Uji Simultan ANOVA $^{\mathrm{a}}$

\begin{tabular}{|c|c|c|c|c|c|c|}
\hline & & & OVA & & & \\
\hline & del & Sum of & $\mathrm{df}$ & Mean & $\mathrm{F}$ & Sig. \\
\hline 1 & $\begin{array}{l}\text { Regressio } \\
\mathrm{n}\end{array}$ & 492,167 & 2 & 246,084 & $\begin{array}{r}46,95 \\
8\end{array}$ &, $000^{\mathrm{b}}$ \\
\hline 1 & Residual & 361,595 & 69 & 5,241 & & \\
\hline & Total & 853,763 & 71 & & & \\
\hline
\end{tabular}

a. Dependent Variable: Tabungan Mudharabah

b. Predictors: (Constant), Bi Rate , Tingkat Bagi Hasil

504Sumber : Hasil penelitian, datadiolah (2019)

Nilai $F_{\text {tabel }}$ diperoleh dari degree of

O0ffeedom(df) untuk uji parsial 2 arah pada sampel 72,

df $=\mathrm{N}-\mathrm{k}-1$ yaitu $72-3-1=69$ dengan $\mathrm{df} 1=2$

$820 \mathrm{~d}$ an df2 $=69$ untuk hipotesis dengan nilai $\mathrm{F}$ pada gnifikansi5\% atau 0,05 , maka nilai $F_{\text {tabel }}$ yang diperoleh adalah sebesar 3,129.

Dari Tabel 4.6 juga dapat diketahui bahwa nilai $F_{\text {hitung }}$ sebesar 46,958 dengan nilai signifikan 
sebesar 0,000 pada taraf kepercayaan $95 \%$. Sedangkan $\mathrm{F}_{\text {tabel }}$ diperoleh nilai sebesar 3,129 pada $\alpha$ $=0.05$. Dengan demikian $F_{\text {hitung }}>F_{\text {tabel }}$ yaitu 46,958 $>3,129$ dan nilai signifikan sebesar 0,000< 0.05.Dari Hasil uji F ini berarti menerima $\mathrm{H}_{4}$.Dengan demikian tingkat bagi hasil dan Bi Rate berpengaruh terhadap tabungan mudharabah Bank Syariah.

\section{Pembahasan}

\section{Pengaruh Tingkat Bagi Hasil Terhadap Tabungan Mudharabah}

Hasil dari penelitian ini menunjukkan bahwa bagi hasil $\left(\mathrm{X}_{1}\right)$ diperoleh angka $\mathrm{t}_{\text {hitung }}$ sebesar 9,685 , sementara nilai $\mathrm{t}$ tabel pada $\alpha=0,05$ adalah sebesar 1.667 artinya $t_{\text {hitung }}>t_{\text {tabel }}$ dengan tingkat signifikansi sebesar lebih kecil dari 0,05 yaitu 0,000. Dengan demikian dapat disimpulkan bahwa $\mathrm{H}_{1}$ diterima dan dapat diartikan bahwa secara tingkat bagi hasil berpengaruh positif dan signifikan terhadap tabungan mudharabah.

Mudharabah merupakan akad kerja sama usaha antara dua pihak, pihak pertama (pemilik dana) menyediakan seluruh dana, sedangkan pihak kedua (pengelola dana) bertindak selaku pengelola. Keutungan ini dibagi oleh mereka sesuai kesepakatan, sedangkan kerugiannya hanya ditanggung oleh pegelola dana.

Tingkat bagi hasil akan mempunyai hubungan yang positif terhadap jumlah Tabungan Mudharabah bank syariah. Asumsinya, bahwa para nasabah menyimpan uangnya di bank konvensional dengan motif profit maximization. Jika manajemen bank syariah juga mempunyai asumsi yang sama, maka bank syariah akan berusaha untuk memberikan tingkat bagi hasil minimal sama atau bahkan lebih tinggi dari pada yang diinfokan oleh bank konvensional. Sebagaimana dalam penelitian terdahulu yang dilakukan oleh Masturoh (2011) menyatakan bahwa return bagi hasil berpengaruh secara signifikan terhadap perkembangan dana pihak ketiga mudharabah. Sedangkan Rizqiana (2010) menyimpulkan bahwa adanya pengaruh antara bagi hasil terhadap jumlah dana deposan menunjukkan bahwa semakin besar bagi hasil, maka semakin besar kemungkinan bank memperoleh modal berupa dana pihak ketiga yaitu deposito syariah. Begitu juga sebaliknya, apabila bagi hasil yang diperoleh sedikit, maka kemungkinan bank memperoleh deposito syariah semakin sedikit.Dari semua penelitian terdahulu menunjukkan bahwa adanya pengaruh antara bagi hasil dengan DPK baik tabungan maupun deposito. Semakin besar bagi hasil, maka semakin besar kemungkinan bank memperoleh modal berupa dana pihak ketiga yaitu tabungan maupun deposito syariah. Begitu juga sebaliknya, apabila bagi hasil yang diperoleh sedikit, maka kemungkinan bank memperoleh deposito syariah semakin sedikit.

\section{Pengaruh BI Rate $\left(\mathrm{X}_{2}\right)$ Terhadap Tabungan Mudharabah}

Hasil dari penelitian ini menunjukkan bahwa $\mathrm{BI}$ rate $\left(\mathrm{X}_{2}\right)$ diperoleh angka $\mathrm{t}$ hitung sebesar 0,228 , sementara nilai $t$ tabel pada $\alpha=0,05$ adalah sebesar 0,820 artinya $\mathrm{t}$ hitung $<\mathrm{t}$ tabel dengan tingkat signifikansi sebesar lebih besar dari 0,05 yaitu 0,820 . Dengan demikian dapat disimpulkan bahwa $\mathrm{H}_{2}$ ditolak dan dapat diartikan bahwa secara parsial BI rate tidak berpengaruh terhadap tabungan mudharabah.

Tida adanya pengaruh antara BI rate terhadap Tabungan Mudharabah disebabkan oleh tingkat keimanan dan pengetahuan masyarakat bahwa dalam agama islam tidak di bolehkan membungakan uang. Sementara prinsip pada bank konvensional adalah memberikan sejumlah bunga kepada nasabah atas jumlah tabungannya. Semakin besar tabungan maka akan semakin besar pula bunga yang ditawarkan.

Namun kondisi tersebut tidak membuat sejumlah masyarakat tergiur akan bunga yang ditawarkan oleh bank konvensional, sehingga meskipun demikian masyarakat akan lebih memilih untuk menabung pada bank syariah.

\section{PENUTUP \\ Kesimpulan}

Kesimpulan yang dapat diambil berdasarkan hasil pengujian hipotesis yang dilakukan yaitu sebagai berikut :

1. Secara parsial variabel tingkat bagi hasilberpengaruh positif dan signifikan terhadap tabungan mudharabah pada Bank Syariah di Indonesia

2. Secara parsial variabel BI rate tidak berpengaruh terhadap tabungan mudharabah pada Bank Syariah di Indonesia.

3. Secara Simultan tingkat bagi hasil dan BI rate berpengaruh positif dan signifikan terhadap tabungan mudharabah pada Bank Syariah di Indonesia

\section{Keterbatasan Penelitian}

Adapun keterbatasan dalam penelitian ini adalah sebagai berikut :

1. Penelitian ini hanya di batasi pada tahun 2013 sampai dengan 2018.

2. Penelitian ini hanya di batasi pada perbankan, serta penelitian ini hanya membatasi variabel independen yaitu tingkat bagi hasil dan $\mathrm{BI}$ rate.

\section{Saran-saran}

Pada penelitian yang akan datang terdapat beberapa hal yang perlu diperhatikan, diantara adalah sebagai berikut:

1. Bagi penelitian selanjutnya, diharapkan penelitian ini dapat dijadikan sebagai rujukan mengenai penelitian selanjutnya dengan menambahkan tahun penelitian serta mengembangkan sejumlah variabel independen. Pengembangan ini perlu dilakukan mengingat banyak variabel lain yang berperan dalam mempengaruhi tabungan mudharabah. 
Bagi perbankan, diharapkan lembaga perbankan mampu mengelola dana yang dihimpun dan di salurkan kepada nasabah sehingga akan mengurangi terjadinya kerugian dan dapat memperoleh keuntungan yang maksimal.

\section{DAFTAR PUSTAKA}

Ana, Maryana. 2001. Pengaruh Tingkat suku Bunga dan Bagi Hasil Terhadap Deposito Mudharabah. Bandung : Universitas Widyatama

Aniswah, Lina. 2011. Pengaruh Tingkat Suku Bunga dan Bagi Hasil Terhadap Volume Deposito Mudharabah(Studi Pada Bank Muamalat Indonesia Tahun 2009-2011). Semarang : Institut Agama Islam Negeri Walisongo

A Reswari, Yustitia dan Ahim, Abdurrahim. 2010. Pengaruh Tingkat Suku Bunga, Jumlah Bagi Hasil, dan LQ 45 terhadap Simpanan Mudharabah pada Bank Syariah Indonesia. Jurnal Akuntansi dan Investasi, Vol 11, No 1, Januari 2010

Dabukke, T. Agnes. 2017. Pengaruh Tingkat Suku Bunga Bank Indonesia ( BI Rate) dan Harga Minyak Dunia Terhadap Inflasi di Indonesia. Pekanbaru: Universitas Riau

D Rusmawati, Yunni. 2016. Pengaruh Tingkat Suku Bunga Terhadap simpananMudharabahpada Bank Umum Syariah di Indonesia. Jurnal Penelitian Ilmu Manajemen, Vol 1 No. 02, Februari 2016

Ghafur, Muhammad. 2003. Pengaruh Tingkat Bagi Hasil, Suku Bunga dan Pendapatan Terhadap Simpanan Mudharabah pada BMI. Yogyakarta

Ghozali, Imam. (2013). Aplikasi Analisis Multivariate dengan Program SPSS. Semarang : BP UNDIP

Haron, Sudin dan Ahmad. 2000. The Effects of Conventional Interest Rates of Profit on Funds Deposited With Islamic Banking System in Malaysia. Internasional Journal of Islamic Financial Services, (Online), Vol. 1 No. 4, http://globalwebspot.com, diakses tanggal 31 Agustus 2018

Ilmiah, Muhibbatul. 2013. Pengaruh Tingkat Suku Bunga, Equivalent Rate Bagi Hasil, Inflasi dan Nilai Kurs Terhadap Simpanan Mudharabah pada Bank Muamalat Indonesia. Yogyakarta : Universitas Negeri Sunan Kalijaga

I Fatmala, Afifudin dan Junaidi. 2015. Pengaruh Tingkat Suku Bunga Deposito Bank Konvensional, Bagi hasil, Likuiditas, dan ROA Terhadap Deposito Mudharabah Pada Bank Syariah di Indonesia. Malang : Universitas Islam Malang

Khaddafi, Muammar. dkk. 2016. Akuntansi Syariah. Medan : Madenatera
Marifat, Ifat. 2016. Analisis Pengaruh tingkat Bagi Hasil Deposito Mudharabah, Jumlah Kantor Layanan, Inflasi, dan PDB Terhadap Jumlah Deposito Mudharabah pada Bank Umum Syariah (BUS) di Indonesia. Jakarta : Universitas Islam Negeri Syarif Hidayatullah

Nurjannah. 2017. Pengaruh Tingkat Suku Bunga pada Bank Umum Terhada Deposito Mudharabah Pada Bank Syariah di Indonesia. Jurnal Samudra Ekonomika, Vol 1, No 1 Maret 2017

Otoritas Jasa Keuangan. 2017. Statistik Perbankan Syariah Indonesia hingga Agustus 2017. Jakarta : OJK.

Putri, Alvyra Nesia Indah dan Indira Januarti. (2014). Faktor-Faktor yang Berpengaruh Terhadap Audit Report Lag Pada Perusahan Manufaktur yang Terdaftar di Bursa Efek Indonesia Tahun 2008-2012, Diponegoro Journal of Accounting, Vol 3 No. 2 Hal 110, Fakultas Ekonomika dan Bisnis Universitas Diponegoro, Semarang, 2014

Purwaningsih, Farida. 2016. Pengaruh tabungan Mudharabah, Pembiayaan MudharabaMusyarakah dan Pendapatan Operasional Lainnya Terhadap Laba Pada Bank Jatim Syariah Periode 2007-2015. Tulungagung : Institut Agama Islam Negeri Tulungagung

Pratiwi, Ayu. 2014. Pengaruh Tingkat Bagi Hasil Terhadap Jumlah Tabungan Mudharabah Pada Perbankan Syariah di Indonesia Periode 2011-2014. Palembang : UIN Raden Fatah

Rizqiana, Rizqi. 2010. Pengaruh Bagi Hasil Terhadap Jumlah Dana Deposito Syariah Mudharabah pada Bank Syariah Mandiri.Jakarta : UIN Hidayatullah

Rahmawati, N. Fitria. 2017.Analisis Pengaruh atingkat Suku Bunga, Tingkat Bagi hasil, dan Financing To Deposit Ratio (FDR) Terhadap Pembiayaan Mudharabah Studi Pada Bank Umum Syariah di Indonesia Periode 2014-2016. Surakarta : Institut Agama Islam Negeri Surakarta

Sudirman. 2016. Pengaruh Tingkat Suku Bunga Deposito Bank Konvensional, Bagi Hasil, dan Likuiditas Terhadap Deposito Mudharabah Pada Bank Syariah di Indonesia. Malang : Universitas Islam Malang

Wulansari, A.M, Dimas. 2012. Pengaruh Tingkat Suku Bunga, Bagi Hasil, dan resiko Likuiditas Terhadap Deposito Mudharabah pada Bank Muamalat Indonesia. Yogyakarta : Universitas Pembangunan Nasional "Veteran"

www.bps.go.id 
